\title{
Cell wall traits as potential resources to improve resistance of durum wheat against Fusarium graminearum
}

Vincenzo Lionetti ${ }^{1}$, Angelica Giancaspro ${ }^{2}$, Eleonora Fabri ${ }^{1}$, Stefania L Giove ${ }^{2}$, Nathan Reem ${ }^{3}$, Olga A Zabotina ${ }^{3}$, Antonio Blanco ${ }^{2}$, Agata Gadaleta ${ }^{2 *}$ and Daniela Bellincampi ${ }^{1^{*}}$

\begin{abstract}
Background: Fusarium graminearum, one of the causal agents of Fusarium Head Blight (FHB, scab), leads to severe losses in grain yield and quality due to the production of mycotoxins which are harmful to human and livestock. Different traits for FHB resistance in wheat were identified for common wheat (Triticum aestivum L.) while the sources of FHB resistance in durum wheat (Triticum turgidum ssp. Durum), one of the cereals most susceptible to F. graminearum infection, have not been found. New lines of evidence indicate that content and composition of cell wall polymers affect the susceptibility of the wall to degrading enzymes produced by pathogens during infection and can play a role in the outcome of host-pathogen interactions. The objective of our research is to identify potential cell wall biochemical traits linked to Fusariosis resistance to be transferred from a resistant common wheat to a susceptible durum wheat line.

Results: A detailed analysis of cell wall composition in spikes isolated from a highly resistant common wheat accession "02-5B-318", a breeding line derived from the FHB-resistant Chinese cv. Sumai-3 and a high susceptible durum wheat cv. Saragolla was performed. Significant differences in lignin monolignols composition, arabinoxylan (AX) substitutions and pectin methylesterification were found between resistant and susceptible plants. We isolated and characterized a pectin methylesterase gene WheatPME1, which we found being down regulated in the FHB-resistant line and induced by fungal infection in the susceptible wheat.
\end{abstract}

Conclusions: Our results indicate cell wall traits differing between the FHB sensitive and resistant wheat genotypes, possibly related to FHB-resistance, and identify the line $02-5 B-318_{R}$ as a potential resource of such traits. Evidence suggests that WheatPME1 is involved in wheat response to $F$. graminearum.

Keywords: Fusarium Head Blight resistance, Wheat, Pectin methylesterase, Cell wall, Fusarium graminearum

\section{Background}

Durum wheat (Triticum turgidum ssp. durum) and common wheat (Triticum aestivum L.) are largely cultivated in European countries and the grain used for the human alimentation (www.FAO.org) and animal feeds. Common wheat allows producing wheat flour and bread, while durum wheat is primarily processed into semolina to produce pasta and couscous and some specialty breads.

\footnotetext{
*Correspondence: agata.gadaleta@uniba.it; daniela.bellincampi@uniroma1.it ${ }^{2}$ Department of Soil, Plant and Food Science (DiSSPA), University of Bari

"Aldo Moro", Via G. Amendola 165/A - 70126, Bari, Italy

'Dipartimento di Biologia e Biotecnologie "Charles Darwin", Sapienza

Università di Roma, Rome, Italy

Full list of author information is available at the end of the article
}

Fusarium graminearum, one of the major global pathogens of cereals, is considered the main causal agent of Fusarium head blight (FHB) disease in wheat [1]. F. graminearum infection causes a significant grain yield and quality loss by producing trichothecene mycotoxins that make harvest unsuitable for human and animal consumption [2]. Host resistance is the primary trait used as a control measure, and its manipulation is the best economic and ecological strategy to reduce damage caused by FHB disease. However, the molecular bases of wheat resistance and susceptibility to $F$. graminerum are scarcely known [3]. Resistance to FHB is a complex and quantitative trait controlled by multiple genes and characterized by 
large genetic variation in wheat gene pool [4]. Several studies aimed to identify traits involved in FHB resistance were carried out using common wheat (Triticum aestivum $L$.) while limited information is available for durum wheat (Triticum turgidum ssp. Durum), which is currently one of the cereals most susceptible to F. graminearum infection [4]. Even though in the last decade different studies were focused on the identification of candidate genes involved in F. graminerum resistance in cultivated or wild durum germoplasm, to date the sources of FHB resistance in durum wheat have not been fully identified [4-7].

F. graminearum preferentially infects wheat spikelets at the stage of anthesis, performs inter and intra-cellular growth and spreads systemically along the rachis [2]. During infection, F. graminearum produces cell wall degrading enzymes (CWDEs), such as pectinases, xylanases and cellulases, to degrade cell wall polysaccharides to penetrate and colonize the host tissues [8-10]. The role of cell wall components in plant resistance to disease has been scarcely studied in grasses. New lines of evidence indicate that content and composition of cell wall polymers affect the susceptibility of cell wall (CW) to CWDEs and can play a role in the outcome of hostpathogen interactions [11-14]. Notably, the extent of CW degradation is often associated with severity of disease [15] Cell wall polysaccharides of the graminaceous monocots (Type II cell wall), consist of a network of cellulose fibers embedded in a matrix of hemicelluloses, such as arabinoxylan (AX) and mixed linkage glucans (MLG), with a minor amount of xyloglucan and pectins [16]. AX (20-40\% of CW dry weight) is composed of a $\beta 1,4$-linked xylose backbone substituted by different monosaccharides, such as arabinose, glucuronic acid and, to lesser extent, galactose [17]. The degree of arabinose substitutions are thought to affect the AX degradability by fungal xylanases [18]. MLGs (10-30\%) is an unbranched polysaccharide consisting of blocks of $(1,4)$ - $\beta$-linked $\mathrm{D}$-glucose residues interrupted by single $(1,3)$ - $\beta$-linkages $[16,19]$. Pectins $(5-10 \%)$ are complex polymers with different structural domains including homogalacturonan (HG), rhamnogalacturonan I (RG-I), rhamnogalacturonan II (RG-II) and xylogalacturonan (XG). Galacturonosyl residues of pectin backbones are methylesterified in Golgi apparatus and secreted into the cell wall in a highly methylesterified form. In the apoplasm, pectins are demethylesterified by pectin methyl esterases (PMEs), which modulate the degree and patterns of methylesterification [20]. The de-methylesterification of pectin affects its interaction with cellulose [21,22] and the formation of crosslinks between pectin chains and xyloglucan or lignin $[23,24]$. The methylesterification makes pectin less susceptible to degradation by pectin degrading enzymes produced by fungal pathogens [5,25-28]. Pectin content and methylesterification in grasses has been associated with plant resistance to pathogens $[5,11,20,29,30]$. Lignin is a complex aromatic heteropolymer comprising a substantial portion $(20 \%)$ of the grasses cell wall. Lignin of monocotyledonous species includes three types of monomers such as p-hydroxyphenyl $(\mathrm{H})$, guaiacyl $(\mathrm{G})$, and syringyl (S) phenylpropanoid monolignols [31,32]. Lignin is an important structural component involved in defense against invasive pathogens, making the cell wall more resistant to CWDEs and also preventing the diffusion of the pathogen-produced toxins [33].

The objective of our research is to identify cell wall biochemical traits useful to improve FHB resistance in durum wheat. To that end, detailed comparative analyses of cell wall composition in spikes isolated from a highly resistant common wheat accession "02-5B-318", a breeding line derived from the FHB-resistant Chinese cv. Sumai-3 and a highly susceptible durum wheat cv. Saragolla were performed. Significant differences in lignin composition, AX substitution and pectin methylesterification were found between resistant and susceptible plants. The genomic sequence and the chromosome location of WheatPME1 gene, differently expressed in resistant and susceptible lines during F. graminearum infection and possibly involved in susceptibility to Fusarium graminearum, was identified and characterized.

\section{Results and discussion}

\section{Assessment of Fusarium symptoms on wheat spikes}

In the present study, the resistance to FHB was analyzed in common wheat accession line 02-5B-318 and in Saragolla, known as one of the most susceptible durum wheat cultivar [34]. Spikes at anthesis were inoculated with fungal spores and disease symptoms were recorded 4, 10 and 20 days post-infection. Symptoms were evaluated as FHB incidence, expressed as percentage of infected spikes per genotype and FHB severity, expressed as percentage of spikelets showing symptoms on the total number of spikelets per spike [35]. Significantly higher FHB incidence and severity were observed in Saragolla (henceforth Saragollas) in comparison with line 02-5B-318 (henceforth $02-5 B-318_{R}$ ) (Figure 1a and b) indicating that the two genotypes exhibited quite extreme phenotypes for FHB resistance/tolerance.

The cell wall of $02-5 B-318_{R}$ spikes contain higher content of $S$ lignin with respect to Saragollas

A detailed analysis of the main structural cell wall components was performed in spikes of $02-5 B-318_{R}$ and Saragolla plants, at anthesis. The characterization of lignin content and composition demonstrated that, while the two genotypes did not differ in the content of lignin, they showed significant differences in monolignols (Table 1). In particular, lignin of $02-5 \mathrm{~B}-318_{R}$ spikes 

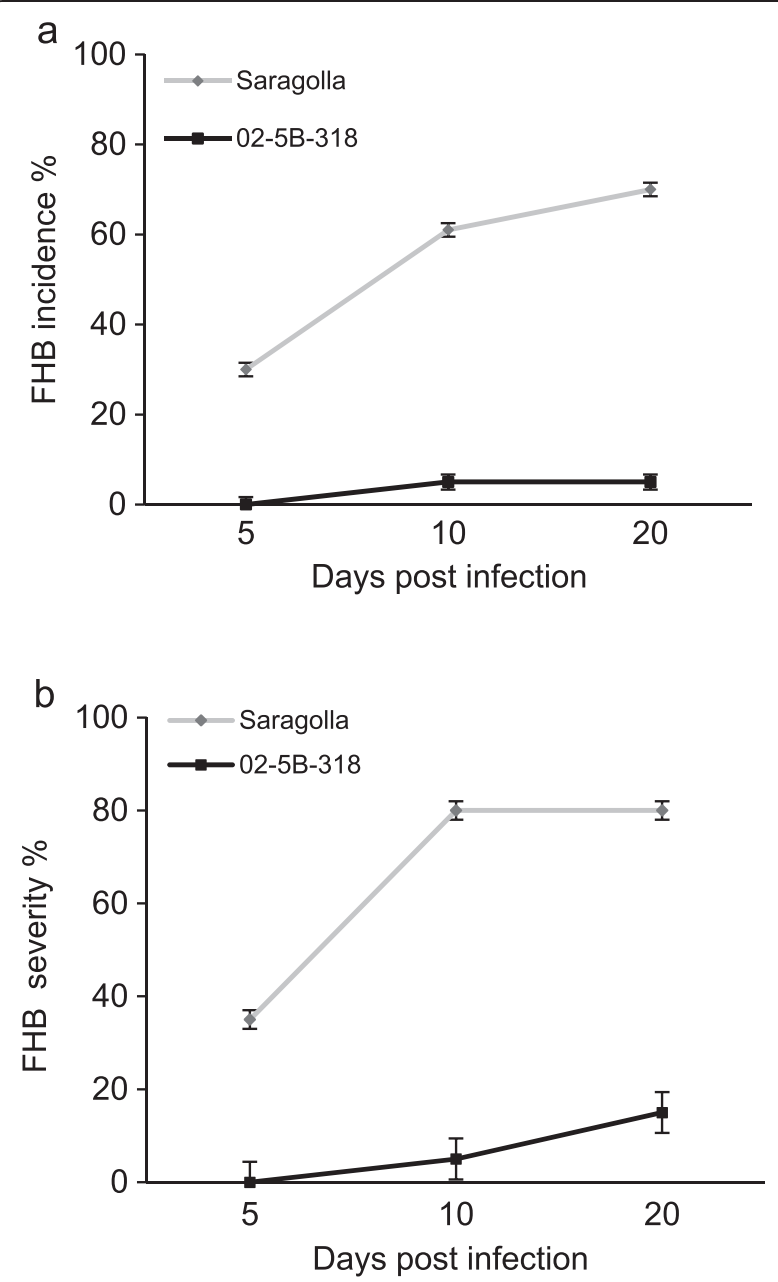

Figure 1 Time-course analysis of FHB symptoms development following $F$. graminearum infection. (a) FHB incidence and (b) FHB severity of Saragollas and $02-5 B-318_{R}$ were evaluated. Data are the average \pm standard deviation of two independent experiments $(n \geq 20)$. The average values of Saragollas and $02-5 B-318_{R}$ lines are significantly different according to Student's t test $(p<0.001)$.

Table 1 Lignin content and monolignol composition in cell walls from spikes of $02-5 B-318_{R}$ and Saragolla $a_{s}$ plants

\begin{tabular}{lll}
\hline & $\mathbf{0 2 - 5 B - 3 1 \mathbf { B } _ { \mathbf { R } }}$ & Saragolla $_{\mathbf{S}}$ \\
\hline Lignin (\%) & $10.65 \pm 1.52$ & $11.23 \pm 2.27$ \\
$\mathrm{~S}(\%)$ & $7.28 \pm 0.91$ & $\mathbf{2 . 3 6} \pm \mathbf{1 . 0 0}$ \\
$\mathrm{H}(\%)$ & $30.65 \pm 1.71$ & $\mathbf{2 0 . 8 6} \pm \mathbf{2 . 6 8}$ \\
G (\%) & $60.24 \pm 4.33$ & $\mathbf{7 6 . 6 8} \pm \mathbf{2 . 1 1}$ \\
S/G ratio & $0.121 \pm 0.02$ & $\mathbf{0 . 0 3 1} \pm \mathbf{0 . 0 1}$
\end{tabular}

Numbers in bold indicate statistically significant differences in each monolignol between the two genotypes, according to Student's t-test $(p<0.05)$. contained a significant higher percentage of syringyl (S) and p-hydroxyphenyl $(\mathrm{H})$ monolignols and a lower amount of guaiacyl (G) monolignols, hence having a higher S/G ratio in comparison with Saragollas genotype. Recent studies aimed to elucidate the effects of lignin composition on the resistance of cell wall to degradation by decay fungi demonstrated that poplar lines extremely rich in syringyl lignin were recalcitrant to fungal degradation [36]. The transcript level of the cinnamoyl-CoA reductase CsCCR4 in the oilseed crop Camelina sativa was observed to be more than 10 times higher in the lines with the higher resistance to Sclerotinia sclerotiorum than in susceptible lines, and this correlated with an high level of constitutive S-lignin [37]. Suppression of $\mathrm{F} 5 \mathrm{H}$ (ferulate/coniferaldehyde 5-hydroxylase) or CAOMT (caffeic acid O-methyltransferase), which reside on a branch pathway converting $\mathrm{G}$ to $\mathrm{S}$ monolignols, greatly reduced the $S / G$ ratio [38]. In addition, the silencing of CAOMT in Triticum monococcum enhanced powdery mildew penetration [39]. Also, the synapyl alcoholspecific peroxidases involved in polymerization of monolignols can be regulated during Fusarium infection. Overall these results suggest that a higher $\mathrm{S}$ lignin content is a possible cell wall biochemical trait related to Fusarium resistance and also propose that genes favoring S-type lignin accumulation might potentially be involved in the resistance to the pathogen.

Xylans in cell wall of $02-5 B-318_{R}$ spikes present a higher degree of arabinosylation with respect to Saragollas

We performed a comparative analysis of $\mathrm{CW}$ polysaccharides of $02-5 B-318_{R}$ and Saragollas wheat plants. The cell walls were extracted from spikes and the cellulose content as well as monosaccharide composition of the non-cellulosic polysaccharides were determined (Figure 2). The amount of the cellulose-derived glucose was not significantly different between the two genotypes indicating that cellulose content is not related to their different FHB resistance/susceptibility (Figure 2a). Monosaccharide composition of non-cellulosic polysaccharides was determined by HPAEC-PAD (high performance anion exchange chromatography-Pulsed Amperometric Detection) after acid hydrolysis of alcohol insoluble solid (AIS) (Figure 2b). As reported for other wheat tissues [40], monosaccharide composition of spike cell walls showed xylose as the main non-cellulosic constituent comprising $70-75 \mathrm{~mol} \%$ of the total sugars, followed by arabinose (about 15\%), glucose and galacturonic acid (about 5\%), galactose (about 2.5\%), and small contents of fucose, rhamnose and glucuronic acid (less than 1\%). The comparison of the composition in monosaccharides between $02-5 \mathrm{~B}-318_{\mathrm{R}}$ and Saragolla $\mathrm{S}_{\mathrm{S}}$ spikes indicated a significantly higher percentage of arabinose, galactose and glucose as well as a lower percentage of 

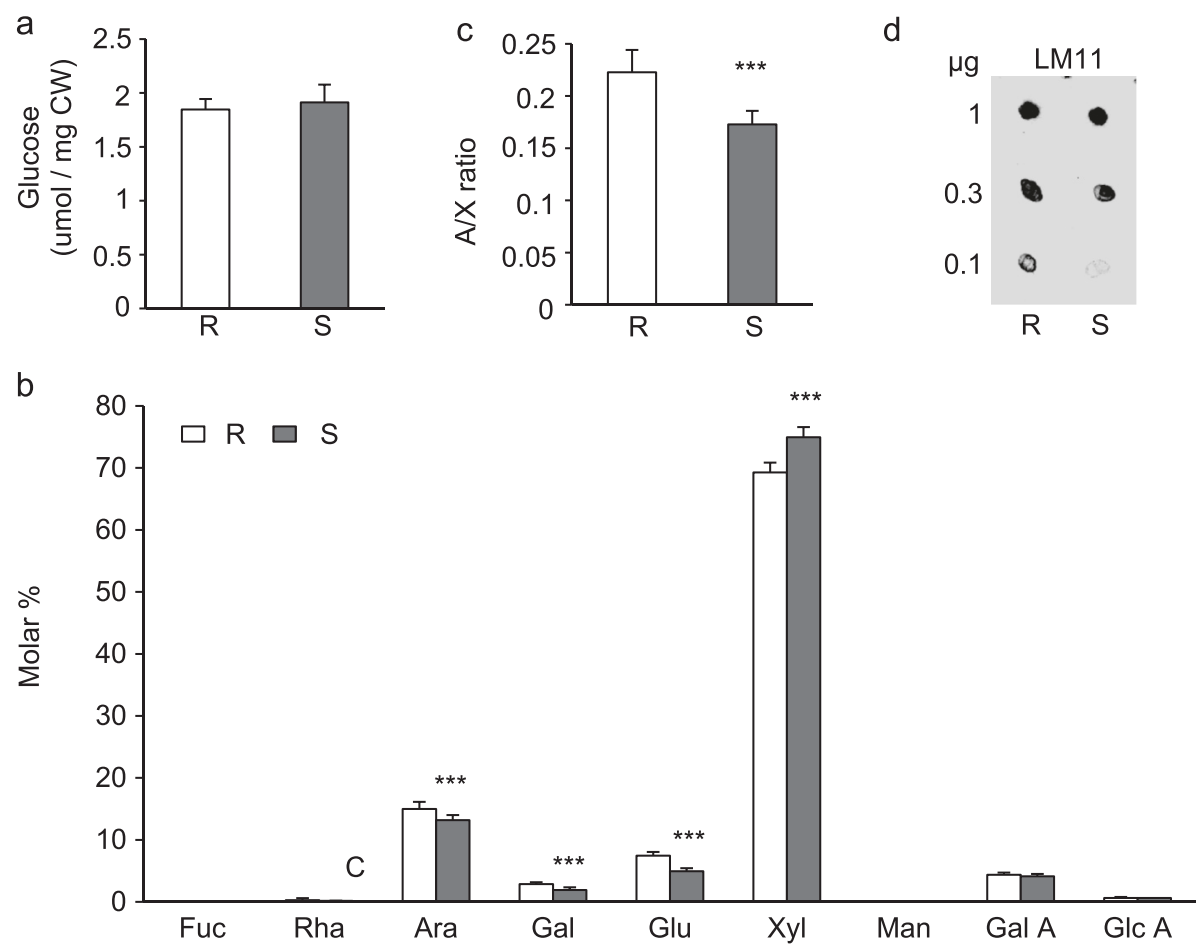

Figure 2 Monosaccharide compositions and immunodot analysis of cell wall polysaccharides in spikes of $02-5 B-318_{R}$ and Saragolla plants. (a) Cellulose-derived glucose, (b) Fucose (Fuc), rhamnose (Rha), arabinose (Ara), galactose (Gal), glucose (Glc), xylose (Xyl), galacturonic acid (Gal A) and glucuronic acid (Glu A) released after 2 M TFA hydrolysis were determined by using a high-performance anion-exchange chromatography with pulsed amperometric detection (HPAEC-PAD) system, (c) Arabinose/Xylose ratio in spikes of 02-5B-318 and Saragollas. Results represent the mean \pm SD of three replicates $(n=6)$. Asterisks indicate data sets significantly different between $02-5 B-318_{R}$ and Saragollas according to Student's t-test $(p<0.001)$. (d) Immunodot analysis for xylan substitution using LM11 antibody. The micrograms of in KOH $1 \mathrm{M}$ hemicellulose fraction from the two genotypes were applied to the nitrocellulose membrane were indicated. The experiments were repeated three times with similar results. $R=02-5 B-318_{R} ; S=$ Saragollas.

xylose in the resistant line as compared to the susceptible one (Figure $2 \mathrm{~b}$ ). The arabinose/xylose ratio (Ara/Xyl), was significantly higher in spikes of $02-5 B-318_{R}$ respect to Saragolla ${ }_{S}$ (Figure 2c). To identify the nature of cell wall polysaccharide differing in the two genotypes, AIS was sequentially fractionated by using solutions with increasingly harsh extraction conditions. Chelating Agent Soluble Solid (ChASS) fractions, mainly containing pectic polysaccharides, and $1 \mathrm{M} \mathrm{KOH}$ and $4 \mathrm{M} \mathrm{KOH}$ fractions, mainly containing hemicelluloses weakly and strongly bound to the cell wall, respectively, were isolated and analyzed for the monosaccharide composition (Table 2). Pectin fractions were not significantly different between the two genotypes. The hemicellulose-enriched fractions from the $02-5 \mathrm{~B}-318_{\mathrm{R}}$ plants contained a significantly higher amount of arabinose, galactose and glucose, a lower amount of xylose and showed a higher Ara/Xyl ratio in comparison with spikes from Saragollas. In grasses, $x y-$ lose and arabinose mainly constitute arabinoxylans (AX) and the combined levels of arabinose and xylose provide a good estimate of arabinoxylan content [16,41]. The percentage of arabinoxylans, calculated as sum of arabinose and xylose, was significantly lower in spikes of 02-5B-318R respect to Saragollas (Table 2). These results therefore indicate a significantly lower amount of arabinoxylans and higher degree of arbinoxylation in the hemicellulose of the $02-5 \mathrm{~B}-318_{\mathrm{R}}$ plants in comparison with Saragolla ${ }_{S}$ and that the differences previously observed between the two genotypes (Figure 2b) can be mainly attributed to the hemicellulose polymers. Monoclonal antibodies can be used to define structural features of polysaccharides in isolated cell wall fractions. In particular LM11 monoclonal antibody is specific to xylan domains enriched in arabinose substitutions [42]. $1 \mathrm{M}$ $\mathrm{KOH}$ fractions extracted from spikes of $02-5 \mathrm{~B}-318_{\mathrm{R}}$ and Saragolla $_{S}$ were analyzed with LM11 antibodies using immunodot assay. A higher level of LM11-binding epitopes was detected in $02-5 B-318_{R}$ spikes in comparison with the FHB susceptible wheat genotype (Figure $2 \mathrm{~d}$ ) confirming the higher degree of xylan arabinosylation of $2-5 B-318_{R}$ spikes in comparison with Saragollas. A negative correlation between the Ara/Xyl ratio and wheat bran digestibility by fungal xylanases have been previously demonstrated [43]. In grasses, arabinose residues of xylans can form 
Table 2 Monosaccharide composition of the ChASS, KOH $1 \mathrm{M}$ and KOH $4 \mathrm{M}$ fractions and Residues

\begin{tabular}{|c|c|c|c|c|c|c|c|c|}
\hline & ChASS & & KOH $1 \mathrm{M}$ & & KOH $4 \mathrm{M}$ & & Residue & \\
\hline & $\bar{R}$ & $S$ & $\bar{R}$ & $\mathrm{~s}$ & $\bar{R}$ & $S$ & $\bar{R}$ & $S$ \\
\hline Fuc & $1.4 \pm 0.2$ & $1.4 \pm 0.2$ & nd & nd & nd & nd & nd & nd \\
\hline Rha & $4.5 \pm 0.5$ & $3.9 \pm 0.4$ & $0.11 \pm 0.02$ & $0.11 \pm 0.01$ & $0.26 \pm 0.01$ & $0.23 \pm 0.03$ & $0.38 \pm 0.04$ & $0.36 \pm 0.07$ \\
\hline Ara & $22.8 \pm 1.2$ & $22.8 \pm 1.9$ & $14.4 \pm 0.8$ & $11.3 \pm 0.1$ & $12.9 \pm 0.3$ & $11.4 \pm 0.6$ & $16.5 \pm 1.6$ & $16.3 \pm 0.6$ \\
\hline Gal & $21.1 \pm 1.5$ & $21.8 \pm 0.8$ & $2.2 \pm 0.1$ & $1.7 \pm 0.1$ & $1.9 \pm 0.2$ & $1.2 \pm 0.1$ & $3.1 \pm 0.8$ & $2.5 \pm 0.3$ \\
\hline Glu & $7.9 \pm 0.6$ & $8.8 \pm 0.9$ & $10.4 \pm 1.1$ & $6.6 \pm 0.5$ & $9.5 \pm 0.9$ & $5.9 \pm 0.1$ & $11.7 \pm 1.7$ & $12.5 \pm 2$ \\
\hline Xyl & $8.6 \pm 0.5$ & $8.7 \pm 0.9$ & $69.8 \pm 1.2$ & $77.2 \pm 0.6$ & $73.0 \pm 1.5$ & $78.7 \pm 0.7$ & $63.0 \pm 2.2$ & $62.6 \pm 1.4$ \\
\hline Man & $10.2 \pm 1.2$ & $9.7 \pm 0.9$ & nd & nd & nd & nd & nd & nd \\
\hline GalA & $21.9 \pm 0.4$ & $21.2 \pm 0.7$ & $2.8 \pm 0.1$ & $2.8 \pm 0.2$ & $2.4 \pm 0.1$ & $2.4 \pm 0.1$ & $5.1 \pm 0.7$ & $5.5 \pm 1.3$ \\
\hline GlcA & $1.5 \pm 0.1$ & $1.5 \pm 0.4$ & $0.26 \pm 0.02$ & $0.27 \pm 0.02$ & $0.18 \pm 0.02$ & $0.18 \pm 0.05$ & $0.18 \pm 0.01$ & $0.21 \pm 0.05$ \\
\hline Ara + Xyl & --- & --- & $83.2 \pm 1.2$ & $86 \pm 0.6$ & $84.9 \pm 1.2$ & $89.1 \pm 0.2$ & $75.6 \pm 2.1$ & $74.8 \pm 2.6$ \\
\hline Ara/Xyl & --- & -- & $0.207 \pm 0.014$ & $0.147 \pm 0.002$ & $0.177 \pm 0.007$ & $0.144 \pm 0.009$ & $0.262 \pm 0.032$ & $0.259 \pm 0.006$ \\
\hline
\end{tabular}

Monosaccharide composition of cell walls from spike of $02-5 B-318_{R}$ and Saragollas wheat plants was determined by HPAEC-PAD. Values are expressed in mol\% for each monosaccharide in each fraction. Value represent means $\pm S D(n=4)$. Number in bold indicate statistically significant differences in each monosaccharides between the two genotypes, according to according to Student's t-test $(p<0.05)$. ChASS, chelating agent-soluble solids; $\mathrm{R}=02-5 \mathrm{~B}-318_{\mathrm{R}} ; \mathrm{S}=\mathrm{Saragolla}$.

ferulic acid-mediated crosslinks between xylan chains and lignin components that limit the enzymatic digestibility of cell walls and improve Fusarium resistance [44-48]. The greater arabinosylation of xylans observed in 02-5B$318_{\mathrm{R}}$ spikes could contribute to a lower degradability of these polymers during Fusarium infection and could consequently represent a potential cell wall trait contributing to FHB resistance. Recently, glycosyltransferases of family 61 were found to be arabinosyltransferases (XATs) in grasses [49]. Interestingly, arabinoxylan also influences desease resistance of barley against the powdery mildew fungus Blumeria graminis $\mathrm{f}$. sp. hordei indicating that in monocot this hemicellulose is important in response to fungal infection [50]. The higher amount of glucose observed in 02-5B-318 ${ }_{\mathrm{R}}$ in comparison with Saragollas (Figure $2 \mathrm{~b}$ and Table 2) indicate a different amount of $(1,3 ; 1,4)-\beta$-Dglucan (Mixed linkage glucans; MLG) in their cell walls. Also in this case CslF and CslH glycosyltransferases implicated in MLG biosynthesis have been identified in grasses [51,52] Consistently, a decreased $\beta$-D-glucan content was observed in susceptible but not in resistant genotypes after inoculation of wheat spikes with Fusarium culmorum [53].

\section{A different degree and pattern of methylesterification was observed in $02-5 B-318_{R}$ and Saragollas spikes}

The degree and pattern of pectin methylesterification impact the plant susceptibility to fungal and bacterial pathogens and affect the outcome of disease [20]. The degree of methylesterification (DM) of cell wall isolated from spikes of $02-5 B-318_{R}$ was significantly higher (a about 30\%) in comparison with Saragollas genotype (Figure 3a). In accordance with this, durum wheat plants overexpressing the pectin methylesterase inhibitor from kiwi, AcPMEI, exhibited a costitutive increased degree of methylesterification (DM) and were more resistant to F. graminerum, Bipolaris sorokiniana and Claviceps purpurea in comparison with untransformed plants [5,30]. It was also demonstrated that highly methylesterified pectins were less susceptible to the action of polygalacturonases (PGs) of both B. sorokiniana and F. graminearum and a reduced growth of both fungal pathogens was detected on cell walls isolated from the transgenic plants indicating that the increased resistance of AcPMEI plants was due to the impaired ability of these fungi to colonize the host tissue [5].




Pectin domains with a random pattern of methylesterification, recognized by the monoclonal antibody LM7, have been demonstrated to be more sensitive to fungal PGs and pectate lyases (PLs) $[54,55]$. Immunodot assay performed with LM7 antibodies on ChASS enriched pectin fraction extracted from spikes of $02-5 B-318_{R}$ and Saragol$\mathrm{la}_{\mathrm{S}}$ showed a significant lower level of LM7-binding epitopes in the $02-5 \mathrm{~B}-318_{\mathrm{R}}$ plants in comparison with the susceptible genotype (Figure $3 \mathrm{~b}$ ). These results indicate that pectin of $02-5 \mathrm{~B}-318_{\mathrm{R}}$ spikes is enriched in domains less susceptible to PGs of F. graminearum secreted at early stages of infection [8]. Noteworthy, LM7 epitopes were also reduced in wheat plants overexpressing AcP$M E I$ and showing improved resistance to F. graminearum [5].

Recent evidence indicates that pectin de-methylesterification is induced at early stages of pathogen infection and favor the outcome of disease [56-58]. To determine whether pectin methylesterification is altered during fungal infection, DM was monitored at different times in uninfected and infected $02-5 B-318_{R}$ and Saragolla spikes. The level of pectin methylesterification was significantly reduced in both genotypes during the early stages of Fusarium infection (Figure 4a). However, while a significant decrease of DM was observed in Saragolla spikes $48 \mathrm{~h}$ hour post inoculation (hpi), the DM reduction in $02-5 B-318_{R}$ infected spikes was evident only after 72 hpi. Notably at 72 hpi, the reduction of DM in the


compared to a $25 \%$ reduction in the resistant genotype.

Studies focused on the analysis of modification of CW composition during fungal infection indicate that CW degradation occur in a sequential manner. Pectic enzymes, mainly including PGs and PLs, are the first to be produced by fungal pathogens during the early stages of infection followed by hemicellulases and cellulases $[11,59,60]$ and although wheat contain a low level of pectin, PGs and PLs produced by Fusarium during infection are important determinants of the outcome of disease [8,61-63]. The analysis of the cell wall degradation by $F$. graminearum was performed by monitoring the monosaccharide composition of AIS isolated from infected spikes at different hpi (Figure 4b). No difference in monosaccharide composition was detected in the cell walls of infected


Figure 4 Characterization of cell wall from spikes of $02-5 B-318_{R}$ and Saragollas plants during Fusarium infection. (a) Quantification of degree of pectin methylesterification (DM) at early stages of Fusarium infection. The DM was performed at the indicated hours post-inoculation (hpi). (b) Monosaccharide compositions of matricial polysaccharides was analysed at 72hpi; M, mock-inoculated plants; Fusarium, fusariuminoculated plants. Data represent the average \pm standard deviation $(n=6)$. The experiment was repeated twice with similar results. The different letters indicate datasets significantly different according to analysis of variance (ANOVA) followed by Tukey's test $(p<0.05)$. Asterisks indicate data sets significantly different between $02-5 B-318_{R}$ and Saragollas according to Student's $t$-test $(p<0.05)$. R =02-5B-31 $8_{R} ; S=$ Saragollas. 
spikes at 24 and $48 \mathrm{hpi}$ (data not shown). At $72 \mathrm{hpi}$, the level of Fuc, Rha, Gal, GalA and GlcA monosaccharides was significantly reduced in Saragolla $a_{S}$ cell walls as compared to $02-5 B-318_{R}$ indicating an higher extent of pectin degradation in the susceptible line. These results suggest that the higher DM and reduced content of pectin domains with random pattern methylesterification in 02-5b$318_{\mathrm{R}}$ spikes as well as the reduced demethylesterification observed during infection can contribute to protect $\mathrm{CW}$ by fungal CWDEs degradation. The hemicellulose alteration was not observed at these stages of infection most likely, because the degradation of hemicelluloses occurs at late stages of infection as reported [8].

\section{Isolation and characterization of WheatPME1}

The degree and pattern of pectin methylesterification in planta is regulated by PMEs. In addition to their important role in plant development $[64,65]$ more recent evidence indicates that plant PMEs are directly involved in plant response against pathogens $[56,57,66]$. With the aim to identify wheat $P M E$ genes involved in Fusarium resistance, we focused our attention on Brachypodium distachyon, which is considered, in respect to vast majority of traits (i.e. cell wall composition, cell wall biosynthesis and plant-pathogen interactions), a convenient model system for monocots [67]. Among different PME sequences, identified using phytozome web site, we focused our attention on Bradi1g16780.1 gene (hereafter named BdPME1). This gene showed the highest sequence similarity with wheat ESTs corresponding to a $P M E$ gene localized on the chromosome $2 \mathrm{~A}$, where the major FHB QTLs were found. The BdPME1 complete genomic sequence consists of $1812 \mathrm{bp}$ corresponding to a mRNA of 1728 bp encoding a 576 amino acids protein. BdPME1 belongs to type I PME containing, in addition to the catalytic PME domain, an N-terminal pro region that share homology with PMEIs [64,68]. BdPME1 gene is located on chromosome 1 of Brachypodium genome and composed of two exons: the first at the 5' end is $498 \mathrm{bp}$ long including the pro region; the second including the PME domain is 1230 bp long. The two exons are separated by a very short intron sequence 84 bp long.

With the aim to isolate the BdPMEI1 orthologous in wheat, the gene sequence was blasted against public databases. Two wheat ESTs, showing a sequence identity higher than $80 \%$ with respect $B d P M E 1$, were found: the first one (BJ252439) entirely covered the BdPME1 longer exon, while the second one (BJ246509) partially matched to the shorter exon at the 5 'end of the gene sequence. The hexaploid wheat cv. Chinese Spring draft genome and the row 454 sequence reads of cv. Chinese Spring annotated at Cereals-DB archive (http://www.cerealsdb. uk.net) were searched to extend both ESTs and three larger consensus contigs were obtained assignable to each of the three A, B and D genomes. The three genes were identified using Softbarry prediction software (http://linux1.softberry.com) and named WheatPME1-A, WheatPME1-B and WheatPME1-D (Additional file 1: Figure S1). They showed a $99 \%$ nucleotide sequence identity among each other (Additional file 2: Figure S2) and the same intron/exons structure comprising two exons of 1053 and $555 \mathrm{bp}$, separated by an intron of $54 \mathrm{bp}$, corresponding to a mRNA sequence of $1608 \mathrm{bp}$ (Figure 5a). The translation of the three WheatPME1-A, WheatPME1-B and WheatPME1-D sequences resulted in a same 537 amino acid protein, sharing an amino acid identity of $77 \%$ with BdPME1 (Additional file 1: Figure S1 and Additional file 3: Figure S3). The Propt. Comp. v.9.0 software indicates WheatPME1 as an "extracellular secreted protein", conforming with the apoplastic locatization of the enzyme. The genomic sequences of WheatPME1 homoeologous genes were obtained in 02$5 \mathrm{~B}-318_{\mathrm{R}}$ (A, B and D genomes) and Saragolla (A and B genomes) using genomic specific primers. The nucleotide sequences and intron/exons structures were respectively identical to the corresponding homoeologous WheatPME1 genes in $\mathrm{A}, \mathrm{B}$ and $\mathrm{D}$ genomes of $02-5 \mathrm{~B}-$ $318_{R}$ and in A and B genomes of Saragollas indicating that the sequence of this gene is strongly conserved in different wheat genotypes. No polymorphism in the WheatPME1 gene was detected between $02-5 \mathrm{~B}-318_{\mathrm{R}}$ and Saragollas. A BLAST search for plant sequences related to WheatPME1 mRNA (BlastX, http://blast.ncbi. nlm.nih.gov) revealed a number of genes which predicted amino acid sequences were analyzed using non-redundant protein database. The search for grass sequences related to WheatPME1 in Phytozome database (http://www. phytozome.net) revealed a number highly conserved PMEs genes, which encode proteins with a slightly variable length ranging from 566 aminoacids (in Setaria italica, Panicum virgatum, Oryza sativa) to 576 aminoacids (in B. distachyon) and with an identity level ranging from 63 to $78 \%$ (Figure 5b). All the selected PMEs belong to type I PME accounting for a smaller pro region at $\mathrm{N}$-terminus of the PME gene, with length range of 151-153 aa, and a longer PME domain with length range of 297-299 aa; consistently with other evidence, these are highly conserved among the selected species [68]. Among the selected WheatPME1 orthologous the gene structure appeared to be highly conserved (Figure $5 b$ ), and always composed by one single exon. The exceptions are rice and Brachypodium distachyon where the sequences are accounted for two gene copies, one is composed by one and another by two exons. Multi-alignment of genomic sequences showed that the different orthologous are characterized by several synthenic regions, particularly one of which showed the same position and orientation 




in all the selected grasses, likely corresponding to the active site of the enzyme (Figure $5 b$ ).

\section{WheatPME1 gene chromosomal position and gene expression in $02-5 B-318_{R}$ and Saragolla $a_{S}$ during \\ F. graminearum infection}

The chromosome position of the homoeologous Wheat PME1 genes was obtained using genetic stocks including nulli-tetrasomic, di-telosomic and a set of wheat deletion bin lines. The homeologous genes were physically located on the short arm of chromosome group 2 in 2BS1-0.53-0.75 and C-2AS5-0.78 bins, respectively. This chromosome position supports a role of WheatPME1 gene in the control of Fusarium resistance since several major QTLs for FHB resistance have been found located in the same bin position with a $\mathrm{R}^{2}$ ranging from $3 \%$ to $27 \%$ [4].

To evaluate whether the expression of WheatPME1 is modulated during Fusarium infection in $02-5 \mathrm{~B}-318_{\mathrm{R}}$ and

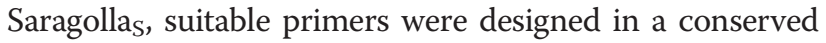
region of the gene sequences in the three genomes and used for qRT-PCR analysis of transcripts from infected and mock-inoculated spikes. WheatPME1 expression level was measured at $0,24,48$ and 72 hours post inoculation (hpi). In both wheat lines, the WheatPME1 expression level at 24 hpi did not show significant difference in comparison with the mock-inoculated controls (Figure 6). In 02-5B-318 ${ }_{\mathrm{R}}$, the level of WheatPME1 expression tends to decrease showing a 1-fold lower expression at $72 \mathrm{hpi}$. It is possible that during Fusarium infection, plants down regulate WheatPME1 to ensure a higher degree of $\mathrm{CW}$ methylesterification which would protect the $\mathrm{CW}$ against Fusarium pectic enzymes. On the contrary, in susceptible Saragollas spikes the expression level of WheatPME1 showed a 2-fold increase at $48 \mathrm{hpi}$ in comparison with the non-infected control, and then dropped back to the basal expression level. Consistently with this observation, the analysis of Wheat $61 \mathrm{k}$ GeneChip annotated at PLEXdb database (http://www.plexdb.org) indicated that the expression of WheatPME1 is only induced by Fusarium in the susceptible hexaploid wheat $\mathrm{cv}$. Chinese spring but not in a line carrying a resistance locus from the wild 

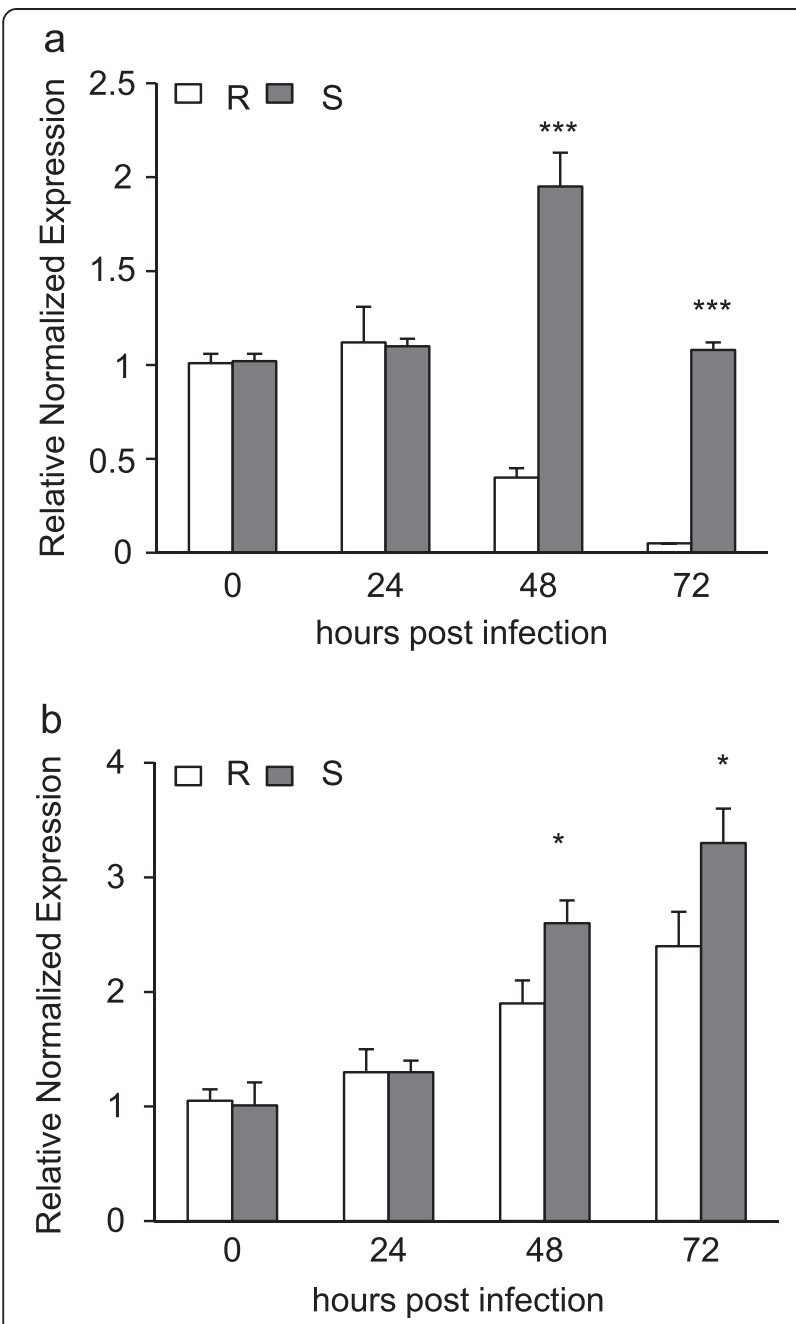

Figure 6 WheatPME1 and F. graminearum $\beta$ TUB2 expression in spikes of resistant $02-5 B-318_{R}$ and susceptible Saragoll ${ }_{S}$ wheat lines during infection. a) WheatPMEl expression was normalized to the average of four different internal references (Actin, CDC, ADP-RF and $R L I$ reported as fold-change with respect to the mock-inoculated control. b) $\beta$ TUB2 expression. The expression level was determined at 24, 48 and 72 hpi. Asterisks indicate data sets significantly different according to Student's $t$-test $\left({ }^{* * *} p<0.001\right.$; ${ }^{*} p<0.05$ ). $R=02-5 B-318_{R}$; $\mathrm{S}=$ Saragollas.

Thinopyrum elongatum chromosome 7E [69] which supports the involvement of this specific PME isoform in wheat response to FHB. The induced expression of WheatPME1 in the susceptible Saragolla line at $48 \mathrm{hpi}$ likely contributes to the observed greater reduction of pectin methylesterification and increased pectin degradation in comparison with 02-5B-318 ${ }_{\mathrm{R}}$, making Saragolla CWs likely more susceptible to fungal CWDEs action and tissue more accessible to fungal colonization. Fusarium growth was assessed by measuring the expression of betatubulin 2 gene ( $\beta$ TUB2; FJ526863.1) in spikes from infected and mock-inoculated $02-5 B-318_{R}$ and Saragolla plants (Figure 6). The $\beta T U B 2$ expression showed increased levels at 24, 48 and 72 hpi in both inoculated lines, however, to a higher extent in the susceptible Saragolla $_{S}$ reflecting an increased fungal growth in these plants. This result also indicates that the repression of WheatPME1 observed in $02-5 \mathrm{~B}-318_{\mathrm{R}}$ was most likely, due to a negative regulation of the gene.

\section{Conclusions}

Different mechanisms of disease resistance of wheat against F. graminearum have been elucidated, mainly in common wheat. These include the specific activation of defense signaling pathways, detoxification/ tolerance and resistance to fungal toxins, and the induction of plant defense secondary metabolites [70,71]. Durum wheat is one of the most susceptible cereals to F. graminearum infection and breeding for the FHB resistance is complicated by the lack of resistance sources. It was speculated that durum wheat either lacks resistance genes or carries effective susceptibility factors and/or suppressor genes that compromise FHB resistance [72,73].

Emerging evidence indicates that content and composition of cell wall polymers affect the susceptibility of cell wall to CWDEs and can play a role in the outcome of host-pathogen interactions [11-14]. In this study we provide a comprehensive overview of cell wall composition of spikes at anthesis, a key developmental stage particularly susceptible to Fusarium infection, from a resistant common wheat and a susceptible durum wheat genotypes. The comparative CW analysis revealed constitutive differences in monolignol composition of lignin, with a higher amount of S-type lignin present in the resistant $02-5 B-318_{R}$ wheat as compared to the Saragolla susceptible plants. We also detected differences in hemicellulose and pectic polymers of the cell wall in spikes of the two genotypes. In particular, resistant line was enriched in AXs with a higher degree of arabinose substitution. The CW of resistant line contained a higher amount of methylesterified pectin with a less random distribution of methylated GalA.

The analysis of degree of methylesterification and monosaccharide composition of the cell wall of spikes at early stages of Fusarium infection indicated an higher demethylesterification and an higher extent of pectin degradation in the susceptible line as compared to $02-5 B-318_{R}$. We propose that cell wall differences between the susceptible and resistant genotype could contribute to the different polysaccharide degradation we observed at early stage of F. graminearum infection as well as could influence the outcome of the disease. Cell wall genes which regulating the cell wall traits identified could be involved in FHB resistance. Among these genes, WheatPME1 was identified, characterized and proposed to participate in the control of pectin methylesterification during the interaction of wheat with $F$. graminearum. In addition to the cell wall 
components here identified, other cell wall traits are known to be involved in monocot resistance to Fusarium [70]. Examples are the cell wall-bound thionins, having growth inhibition activity toward pathogens as well as callose and structural hydroxyproline-rich glycoproteins, both involved in cell wall reinforcement at the site of pathogen infection [14,74,75]. Moreover, inhibitors of CWDEs such as polygalacturonase inhibiting proteins (PGIPs), PMEIs, Triticum aestivum xylanase inhibitors (TAXIs) and xylanase inhibitor proteins (XIPs), influencing cell wall degradability during infection, have been associated to wheat resistance against Fusarium $[6,11,76]$. All these cell wall traits are potential molecular markers useful in plant breeding programs targeted to the selection of wheat varieties with a durable resistance to Fusariosis.

\section{Methods}

\section{Growing condition of wheat and pathogenicity tests}

Wheat seeds were surface-sterilized in Sodium hypochlorite and transferred on petri dishes containing $3 \mathrm{MM}$ paper soaked with water. Plates were stored at $4^{\circ} \mathrm{C}$ in the dark for 24-48 $\mathrm{h}$ and transferred in a growth chamber at $23^{\circ} \mathrm{C}$ in the dark for 15 days. Plants grown in a controlled environmental chamber maintained at $22^{\circ} \mathrm{C}, 70 \%$ humidity with a 16 hours photoperiod $(300 \mu \mathrm{E} \mathrm{m}-2 \mathrm{~s}-1)$.

Pathogenicity tests were conducted using the Fusarium resistant common wheat line, accession n. 02-5B-318 (a breeding line derived from cv. Sumai3, kindly provided by dott. Stefano Ravaglia, S.I.S., Bologna, Italy) and on the susceptible durum wheat cv. Saragolla. Uniform inoculum pressure was applied during flowering by using the Fusarium graminearum PH 1 isolate (kindly provided by prof. Quirico Migheli, University of Study of Sassari, Italy). Plants were artificially inoculated by spraying on each plants $100 \mathrm{~mL}$ of a suspension containing a mixture of conidia of F. graminearum (about $1.0 \times 105$ conidia per $\mathrm{mL}$ ). Fusarium strain was grown for one week on PDA (Potato Dextrose Agar) and conidia were isolated by growing pieces of mycelium in shaking cultures in 2 L PIREX flasks containing $1 \mathrm{~L}$ sterile CMC (Carboxylmethyl-cellulose) medium (15gr CMC, $1 \mathrm{gr} \mathrm{NH}_{4} \mathrm{NO}_{3}$; $1 \mathrm{gr}$ $\mathrm{KH}_{2} \mathrm{PO}_{4} ; 0.5$ gr $\mathrm{MgSO}_{4} * 7 \mathrm{H}_{2} 0$; 1 gr yeast extract; $50 \mathrm{ug} / \mathrm{mL}$ chloramphenicol). After 5-day incubation in the dark at $25^{\circ} \mathrm{C}$ shaking at $150 \mathrm{rpm}$, flasks content was filtered through two layers of cheesecloth by centrifugation at $3,000 \mathrm{rpm}$ for $10 \mathrm{~min}$; pellet was re-suspended in sterile water and centrifuged again. Filtered conidia were finally re-suspended in $10 \mathrm{~mL}$ of sterile water. The concentration of the inoculum was measured with a Burker camera (HBG Henneberg-Sander GmbH, Lutzellinden, Germany) using a light-microscope.

Twenty plants for 02-5B-318 and Saragolla line were artificially spray-inoculated during anthesis with a $10^{6} / \mathrm{mL}$ distilled-water macroconidia suspension, for each plant
5 spikes were chosen for a total of 100 spikes per lines. Fusarium head blight (FHB) incidence and severity were recorded five, ten and twenty days after inoculation on both infected and mock-inoculated (controls) wheat plants: FHB severity was averaged as the percentage of infected spikelets per plant, while FHB incidence was averaged as the number of infected spikes per plant; a mean value of at least 20 plants per genotype was assessed. Infection experiments were statistically evaluated by performing analysis of variance followed by the Student's $t$ test.

\section{Alcohol-insoluble solids (AIS) extraction}

Wheat spikes were collected at anthesis stage and infected spikes were collected after 24, 48 and 72 hours post Fusarium inoculation. Tissues excised from the central part of each spike, including rachis and spikelets were ground to a fine powder with a mortar and pestle in presence of liquid nitrogen. Milled tissue $(200 \mathrm{mg})$ was washed twice in a pre-warmed $\left(70^{\circ} \mathrm{C}\right) 70 \%$ ethanol, vortexed, and pelleted by centrifugation at $25,000 \mathrm{~g}$ for $10 \mathrm{~min}$. The pellet was suspended with a chloroform: methanol mixture $(1: 1, \mathrm{v} / \mathrm{v})$ and shaked for $30 \mathrm{~min}$ at room temperature. Samples were pelleted by centrifugation at $25,000 \mathrm{~g}$ for $10 \mathrm{~min}$. Pellets were re-suspended in $1 \mathrm{ml} \mathrm{80 \%}$ acetone and spin at 25,000 g for $5 \mathrm{~min}$. Supernatants were discarded and pellets were dried at room temperature over-night.. Starch was removed by treating the AIS with the porcine Type I-A $\alpha$-amylase (100 U g-1 AIS; product number A4268; Sigma-Aldrich) in a $100 \mathrm{mM}$ potassium phosphate buffer $\mathrm{pH} 7.5 \mathrm{mM} \mathrm{NaCl}$ and $0.02 \%$ (w/v) NaN3 for 24 hours at $37^{\circ} \mathrm{C}$. The suspension was centrifuged at $25,000 \times \mathrm{g}$ for 20 minutes, and pellet was then washed with distilled water and $80 \%$ acetone.

\section{Lignin content and monolignol composition}

Acetyl bromide lignin in de-strached AIS from the spikes of both wheat varieties was determined according to [77] with some modifications. Briefly, $3 \mathrm{mg}$ of AIS were placed in glass vials, and then $200 \mu \mathrm{l} 25 \%$ acetyl bromide in acetic acid and $600 \mu \mathrm{l}$ of acetic acid (glacial) were added. Mixtures were incubated at $50^{\circ} \mathrm{C}$ for $2 \mathrm{~h}$, with occasional shaking. $15 \mu \mathrm{l}$ of reaction mixture after cooling was transferred to 96-well plate (UV transparent), and $15 \mu \mathrm{l} 0.3 \mathrm{M} \mathrm{NaOH}, 5 \mu \mathrm{l} 0.5 \mathrm{M}$ hydroxylamine hydrochloride and $65 \mu \mathrm{l}$ acetic acid (glacial) were added. After shaking, optical density at $280 \mathrm{~nm}$ against blanks (all reagents without AIS samples) was measured using plate reader. Lignin concentration was determined using the following equation: \% lignin content $=$ (absorbance $\times$ 100)/SAC $\times$ AIS concentration $\left(\mathrm{g}^{-1}\right)$ where SAC is the specific absorption coefficient of lignin [78]. Specific monolignol composition was determined using Pyrolysis-GCMS. De-starched AIS (3 mg) were single-shot pyrolized at 
$500^{\circ} \mathrm{C}$ and the volatile compounds were separated on HP-5 MS column $(30 \mathrm{~m} \times 0.25 \mathrm{~mm}$, Agilent Technologies Inc, USA) using GC system (6890 N GC-system interfaced to 5975B inert MSD, Agilent Tech., USA). Oven temperature was initially set at $50^{\circ} \mathrm{C}$ and ramped to $280^{\circ} \mathrm{C}$ over a period of $53 \mathrm{~min}$. Helium was the carrier gas for the volatile compounds and the split ratio was set at 50:1. Peak identification was performed by comparison of sample spectra with those published by [79]. The monolignol composition was calculated as \%, combining the peak areas of similar type of lignin.

\section{Determination of the degree of methylesterification}

De-starched AIS (4 mg) were saponified by suspending them in $60 \mu \mathrm{l} \mathrm{H}_{2} \mathrm{O}$ up and $20 \mu \mathrm{l}$ of $1 \mathrm{M} \mathrm{NaOH}$. The solution was incubated at room temperature for $1 \mathrm{~h}$ and afterward neutralized with $\mathrm{HCl}$. After centrifugation at $25,000 \times g$, aliquots of the supernatant $(50 \mu \mathrm{l})$ of $02-5 \mathrm{~B}$ $318_{R}$ and Saragollas were loaded in microtiter plates (96-well cod.9018 from Costar, Cambridge, MA, U.S.A.). Alcohol oxidase $(50 \mu \mathrm{l})$ was added to each well $(0.03$ units in $0.1 \mathrm{M}$ sodium phosphate, $\mathrm{pH}$ 7.5) (Sigma, St. Louis), and this mixture was incubated at room temperature for $15 \mathrm{~min}$ on a shaker. Thereafter, $100 \mu \mathrm{l}$ of a mixture containing $0.02 \mathrm{M}$ 2,4-pentanedione in $2 \mathrm{M}$ ammonium acetate and $0.05 \mathrm{M}$ acetic acid was added to each well. After $10 \mathrm{~min}$ of incubation at $68^{\circ} \mathrm{C}$, samples were cooled on ice and absorbance was measured at $412 \mathrm{~nm}$ in a microplate reader (ETI-System reader; Sorin Biomedica Cardio S.p.A., Saluggia, Italy. The amount of methanol was estimated as described [80]. For uronic acid quantification, $4 \mathrm{mg}$ saponified AIS samples were incubated in $200 \mu \mathrm{l}$ of $2 \mathrm{M}$ Trifluoracetic acid (TFA) at $121^{\circ} \mathrm{C}$. After 1.5 hours, $200 \mu \mathrm{l}$ of isopropanol was added and the mixtures evaporated at $40^{\circ} \mathrm{C}$ with a stream of $\mathrm{N}_{2}$ gas. This step was repeated twice and samples were dried at room temperature overnight. The TFA hydrolyzed monosaccharides were suspended in $200 \mu \mathrm{l}$ of water and the Uronic acid content in the supernatant was quantified colorimetrically using the automated sulfamate/m-hydroxy diphenyl assay [81] and galacturonic acid (Fluka 48280) as standard. The degree of methylesterification was expressed as methanol to uronic acid molar ratio (\%).

\section{Cell wall fractionation and monosaccharides composition}

To isolate fractions enriched in various cell wall components, AIS were subjected to sequential extraction buffers (at final concentration of $30 \mathrm{mg} / \mathrm{ml}$ ) in constant mixing for 24 hours at room temperature. The following order was followed: $50 \mathrm{mM}$ ammonium oxalate (Chelating Agent Soluble Solid, ChASS) pH 5.2 with $0.02 \%$ sodium azide; $1 \mathrm{M} \mathrm{KOH}, 1 \%(\mathrm{w} / \mathrm{v})$ of sodium borohydride with $0.02 \%$ sodium azide and $4 \mathrm{M} \mathrm{KOH}$ with $1 \%(\mathrm{w} / \mathrm{v})$ of sodium borohydride with $0.02 \%$ sodium azide. The $1 \mathrm{MKOH}$ and $4 \mathrm{M} \mathrm{KOH}$ fractions were neutralized using glacial acetic acid. All of the extracts were dialyzed against four changes of $4 \mathrm{~L}$ of deionized water and then lyophilized. For each genotype six independent replicates were analyzed. The monosaccharide composition of destarched AIS, the ChASS, $1 \mathrm{M} \mathrm{KOH}, 4 \mathrm{M} \mathrm{KOH}$ fractions and of residue, all hydrolysed with TFA was determined by HPAEC-PAD using a PA20 column (Dionex, CA, USA). Peaks were identified and quantified by comparison to a standard mixture of rhamnose (Rha), arabinose (Ara), fucose (Fuc), galactose (Gal), glucose (Glc), xylose (Xyl), mannose (Man), galacturonic Acid (GalUA), and glucuronic acid (GlcUA) (Sigma-Aldrich).

The crystalline cellulose was determined as previously described [82]. The cellulose derived glucose content in destarched AIS was determined by an anthrone colorimetric assay [83] with glucose (Sigma G8270) as a standard.

\section{Immunodot assay}

For each experiment, ChASS and $\mathrm{KOH} 1 \mathrm{M}$ fractions were applied as $1 \mu \mathrm{L}$ aliquots to nitrocellulose membrane (0.45 $\mu \mathrm{m}$ pore size; Bio-Rad, Hercules, CA, USA) in a threefold dilution series. Arrays were incubated for 1 hour in $5 \%(\mathrm{w} / \mathrm{v})$ milk protein (MP; Bio-Rad) in PBS pH 7.8 (MP-PBS), and probed for 1.5 hours with primary LM7 and LM11 monoclonal antibodies (purchased from PlantProbes, Paul Knox Cell Wall Lab, University of Leeds,Leeds, UK) diluted 1:20 in 3\% MP-PBS. After extensive washes in PBS, arrays were incubated with anti-rat conjugated to horseradish peroxidase (A7058; SigmaAldrich) diluted 1:1000 in MP-PBS buffer. After washing in PBS, LM11 arrays was developed using 4-chloro-1naphthol [84] and, due to a weak signal, LM7 was developed using ECL detection reagent (Amersham).

\section{Bioinformatic analysis}

In order to identify homologous proteins to wheat methylesterase enzyme, a bioinformatic analysis was carried out on grass species (Sorghum bicolor, Zea mays, Setaria italica, Panicum virgatum, Oryza sativa and Brachypodium distachyon) annotated in Phytozome v.9.1 database (http://www.phytozome.net). Brachypodium BdPME1 complete genomic sequence was used as the initial query in a BLAST-search against wheat EST (Expressed Sequence Tags) database at NCBI (http://blast.ncbi.nlm.nih.gov), with the aim to retrieve sequences with a high similarity score $(>80 \%)$. Each suitable EST was finally searched for similarity in the Chinese Spring database at Cereal DB (http://www.cerealsdb.uk.net/search_reads.htm), to extract 454 reads and obtain larger consensus contigs of the hexaploid reference cultivar using an e-value cut-off of $\mathrm{e}^{-5}$. 


\section{Isolation and characterization of WheatPME1 sequence in wheat lines}

WheatPME1 gene isolation was conducted in the $02-5 \mathrm{~B}-$ 318 accession of $T$. aestivum and in the durum wheat cv. Saragolla, respectively FHB-resistant and susceptible. Genomic DNA was isolated from the two wheat lines according to the extraction protocol by [85] starting from $0.1 \mathrm{gr}$ of fresh leaves, then checked for quality and concentration at a Nanodrop device (Thermo Scientific, Walthman, MA, USA). Purity of extracted DNA was assessed by measuring $260 \mathrm{~nm} / 280 \mathrm{~nm}$ ratio, with a value of approximately 1.8-2 indicating a good quality.

Genomic DNA was PCR-amplified with several primer pairs opportunely designed by OligoExplorer software on Brachypodium genomic sequence, Chinese Spring ESTs and consensus contigs, in order to cover the entire gene sequence. All the amplification reactions were initially carried out in a gradient of annealing temperature in order to check for primer specificity and identify the optimal annealing conditions for each primer combination. PCR reactions were conducted in a total volume of $25 \mu \mathrm{l}$ containing $100 \mathrm{ng}$ of template gDNA, $250 \mathrm{nmol} / \mathrm{L}$ of each primer, $1 \mathrm{X}$ reaction Buffer $(10 \mathrm{mmol} / \mathrm{L}$ Tris- $\mathrm{HCl}$, $\mathrm{pH} 8.3 ; 10 \mathrm{mmol} / \mathrm{L} \mathrm{KCl}), 200 \mu \mathrm{mol} / \mathrm{L}$ of each dNTP, $2.5 \mathrm{mmol} / \mathrm{L}$ of $\mathrm{MgCl}_{2}$, and 1 unit of Taq DNA polimerase (EuroTaq, Euroclone ${ }^{\oplus}$ ). Amplifications were run in a MyCycler ${ }^{\mathrm{TM}}$ Personal Thermal Cycler (Bio-Rad ${ }^{\oplus}$ ) according to the following protocol: $5 \mathrm{~min}$ at $95^{\circ} \mathrm{C}$, followed by 32 cycles of: $1 \mathrm{~min}$ at $95^{\circ} \mathrm{C}, 1 \mathrm{~min}$ at the given annealing temperature, and $2 \mathrm{~min}$ at $72^{\circ} \mathrm{C}$, followed by a final extension step of $15 \mathrm{~min}$ at $72^{\circ} \mathrm{C}$. Finally, PCR products were checked for the expected molecular size by visualization on $1.5-2 \%$ agarose gel stained with GelRed $^{\oplus}$ dying solution (Biotium, Inc., Hayward, CA).

For the chromosomal localization of WheatPME1 genes, nulli-tetrasomic lines (NTs) of Triticum aestivum cv. Chinese Spring $[86,87]$ were used to physically localize PME markers to chromosomes. Chinese Spring ditelosomic lines [88] were used for the assignment of markers to each chromosomal arm. Physical location on chromosome bins of each PCR fragment was obtained using a set of common wheat deletions lines dividing genome chromosomes into bins (kindly provided by B. S. Gill, USDA-ARS, Kansas State University) [89]. Single-band PCR products were directly purified from a volume of about $100 \mu \mathrm{l}$ using the EuroGold Cycle Pure Kit (Euroclone ${ }^{\ominus}$ ) following the manufacturer instructions, with the only exception of using sterile deionized water rather than the supplied elution buffer, to increase the efficiency of following sequencing reactions. Purified DNA fragments were checked on 1.5-2\% agarose gel stained with Gel-Red ${ }^{\oplus}$ dye solution, then evaluated for concentration by detecting absorbance at a $260 \mathrm{~nm}$ wave length at a Nano Drop device (Thermo
Scientific ${ }^{\odot}$ ). Sequencing analyses were performed for each fragment in both strands by BMR Genomics S.r.l (Padova). Sequence assembly was obtained with Codone Code Aligner and Geneious softwares. Multi-alignments of gene sequences between 02-5B-318 and Saragolla were carried out by ClustalW (www.ebi.ac.uk) and BLAST (http://blast.ncbi.nlm.nih.gov). Gene structure prediction was performed by the FGENESH on-line tool (http:// linux1.softberry.com/cgi-bin/programs/gfind/bestorf.pl).

\section{Gene expression analysis}

Total RNA was isolated from spikes of infected and mockinoculated (control) plants of both resistant 02-5B-318 and susceptible Saragolla at 24, 48 and 72 hours post inoculation. For each sample three biological replicates were collected from different plants. Tissues were harvested in each phase, immediately frozen in liquid nitrogen and stored at $-80^{\circ} \mathrm{C}$ until RNA extraction. Total RNA was extracted using the RNeasy Plant Mini Kit (Qiagen ${ }^{\odot}$ ) and checked on $1.5 \%$ denaturing agarose gel; amount and purity were determined with a Nano-Drop spectrophotometer. All RNA samples were led to the same concentration $(1 \mu \mathrm{g} / \mu \mathrm{l})$ and reverse-transcribed into double stranded cDNA by using the Quanti-Tect Reverse Transcription Kit (Qiagen $^{\circ}$ ) following the manufacturer instructions, after a prior treatment with a DNA Wipeout Buffer for the removal of gDNA contamination.

Primer pairs were designed by using OligoExplorer software on a conserved pme nucleotide region between the three wheat genomes, in order to determine the total pectin methyl-esterase gene expression in the two wheat lines. As shorter amplicons work more efficiently, primers were designed to amplify small DNA fragments in the range of 50-200 bp. Actin, CDC (Cell Division Control), ADP-RF (ADP-Ribosilation Factor) and RLI (RNase $\mathrm{L}$ Inhibitor-like protein) genes were used as internal references to normalize $P M E$ expression data. Specific primers for Fusarium $\beta$-tubulin 2 ( $\beta T U B 2)$ gene were used to assay fungal infection in both inoculated and noninoculated wheat samples (Additional file 4: Table S1).

In order to identify the best temperature to ensure primer specificity, standard PCR on CDNA were performed with a gradient of annealing temperatures (ranging between $55^{\circ} \mathrm{C}$ and $65^{\circ} \mathrm{C}$ ) for both target and reference primer pairs, by using high fidelity MyTaq DNA polymerase (BioLine). Amplicon specificity was confirmed for each primer pair by checking the presence of single PCR products of expected molecular size on $2 \%(\mathrm{w} / \mathrm{v})$ agarose gel stained with Gel $\operatorname{Red}^{\oplus}$ dying solution, and by direct sequencing of the amplified fragments (BMR Genomics, Padova, Italy).

Primer concentration was optimized for each gene in preliminary Real-Time amplification experiments by running reactions with different combinations of forward 
and reverse primers in the final mix $(100,300,500$ and $900 \mathrm{nM}$ ), then choosing those giving the highest endpoint fluorescence and a low Cq value. Primer specificity was also checked by performing melting curves of PCR products following Real Time amplifications.

qRT-PCR reactions were performed using EvaGreen ${ }^{\circ}$ chemistry in the CFX96 ${ }^{\text {tix }}$ Real-time PCR System (Bio-Rad) following these conditions: $95^{\circ} \mathrm{C}$ for $3 \mathrm{~min}$, followed by 40 cycles of: $95^{\circ} \mathrm{C}$ for $10 \mathrm{sec}$ and $60^{\circ} \mathrm{C}$ for $30 \mathrm{sec}$. In each qPCR experiment $1 \mu \mathrm{l}$ of a 1:10 dilution of cDNA was used in a final volume of $10 \mu \mathrm{l}$ containing $5 \mu \mathrm{l}$ of SsoFast EvaGreen ${ }^{\circ}$ SuperMix 10X (Bio-Rad) and a primer concentration of $500 \mathrm{nM}$ for WheatPME1, and $100 \mathrm{nM}$ for Actin, $C D C, A D P-R F$ and $R L I$. Three independent amplification reactions (technical replicates) were carried out for each biological replicate.

PCR reaction efficiency was calculated for both target and reference genes by generating six-point standard curves of three-fold serial dilutions of cDNA. Standards were run in the same amplification plate of the unknown samples. All experiments were performed in Hard-Shell 96-well skirted PCR plates (HSP9601) with Microseal $^{\circ}$ 'B' Adhesive Seals (MSB-1001) from Bio-Rad'.

Data analyses were performed with the CFX Manager ${ }^{\text {Tm }}$ 3.1 software, using the Normalized Expression mode $\left(\Delta \Delta \mathrm{C}_{\mathrm{q}}\right)$ which calculated the relative quantity of target (WheatPME1) normalized to the relative quantity of internal references (geometric mean of multiple reference genes). For both target and reference genes, relative expression was calculated as fold-change respect to the mock-inoculated controls at each harvesting stage, and determining the standard deviation (SD) for the relative quantity. All the results were analyzed by ANOVA.

\section{Availability of supporting data}

All the supporting data are included as additional files in this manuscript.

\section{Additional files}

Additional file 1: Figure S1. WheatPMElgenes and protein sequences Fasta sequences of hexaploid cV Chinese Spring WheatPME1-A, WheatPME1-B and WheatPME1-D genes and encoded polypeptides.

Additional file 2: Figure S2. Multiple alignment of WheatPME1 genes identified in Triticum aestivum, cv. Chinese Spring in the corresponding A, $B$ and $D$ genomes. In yellow are highlighted the SNPs between the A/D and $B$ genomes.

Additional file 3: Figure S3. Multiple alignment of WheatPME1 from A, $\mathrm{B}$ and D genomes of Triticum aestivum CV. Chinese Spring and from Brachypodium distachyon (BdPME1). The yellow box indicates the pro region, whereas the green box corresponds to the PME domain. The protein is reported in $\mathrm{C}$ terminus- $\mathrm{N}$ terminus orientation.

Additional file 4: Table S1. Primer pairs sequences for housekeeping and target genes.

\section{Abbreviations}

FHB: Fusarium Head Blight; CW: Cell wall; CWDEs: Cell wall degrading Enzymes; PME: Pectin Methylesterase; PMEl: Pectin Methylesterase inhibitor; XIP: Xylanase inhibitor protein; PGIP: Polygalacturonase inhibiting protein; TAXI: Triticum aestivum xylanase inhibitor; QTL: Quantitative trait Loci; EST: Expressed sequence tags; CDC: Cell division control; ADP-RF: ADP-ribosilation factor; RLI: RNase L inhibitor-like protein; $\beta$ TUB2: $\beta$-tubulin 2; SD: Standard deviation; Cq: Quantification cycle; qRT-PCR: Quantitative reverse-transcription PCR.

\section{Competing interests}

The authors declare that they have no competing interests.

\section{Authors' contributions}

$L V, A G a$, and DB designed experiments. LV and EF perform the characterization of cell wall polysaccharide composition and structure. NR and OAZ perform the characterization of lignin composition. SLG performed FHB disease symptoms assessment and RNA extraction. AGi performed qRT-PCR experiments, characterization and isolation of WheatPME1. AB contributed to data interpretation and assisted in drafting the manuscript. LV, AGi, AGa, OAZ, and DB wrote the paper. All authors read and approved the final manuscript.

\section{Acknowledgements}

The work in the labs of DB and AGa was supported by Ministero dell'Istruzione, dell'Universita' e della Ricerca; PRIN Grant n. 2010T7247Z. The work in the lab of OAZ was supported by National Science Foundation: grant n.1121163, 2011-2015).

\section{Author details}

'Dipartimento di Biologia e Biotecnologie "Charles Darwin", Sapienza Università di Roma, Rome, Italy. ${ }^{2}$ Department of Soil, Plant and Food Science (DiSSPA), University of Bari "Aldo Moro", Via G. Amendola 165/A - 70126, Bari, Italy. ${ }^{3}$ Roy J. Carver Department of Biochemistry, Biophysics and Molecular Biology, lowa State University, Ames, lowa 50011, USA.

Received: 29 July 2014 Accepted: 5 December 2014

Published online: 19 January 2015

\section{References}

1. Kazan K, Gardiner DM, Manners JM: On the trail of a cereal killer: recent advances in Fusarium graminearum pathogenomics and host resistance. Mol Plant Pathol 2012, 13:399-413.

2. Brown NA, Urban M, Van De Meene AML, Hammond-Kosack KE: The infection biology of Fusarium graminearum: Defining the pathways of spikelet to spikelet colonisation in wheat ears. Fungal Biol 2010, 114:555-571.

3. Bischof M, Eichmann R, Huckelhoven R: Pathogenesis-associated transcriptional patterns in Triticeae. J Plant Physiol 2011, 168:9-19.

4. Buerstmayr $H$, Ban T, Anderson JA: QTL mapping and marker-assisted selection for Fusarium head blight resistance in wheat: a review. Plant Breed 2009, 128:1-26.

5. Volpi C, Janni M, Lionetti $V$, Bellincampi D, Favaron F, D'Ovidio R: The Ectopic Expression of a Pectin Methyl Esterase Inhibitor Increases Pectin Methyl Esterification and Limits Fungal Diseases in Wheat. Mol Plant-Microbe Interact 2011, 24:1012-1019.

6. Moscetti I, Tundo S, Janni M, Sella L, Gazzetti K, Tauzin A, Giardina T, Masci S, Favaron F, D'Ovidio R: Constitutive Expression of the Xylanase Inhibitor TAXI-III Delays Fusarium Head Blight Symptoms in Durum Wheat Transgenic Plants. Mol Plant-Microbe Interact 2013, 26:1464-1472.

7. Miedaner T, Longin CFH: Genetic variation for resistance to Fusarium head blight in winter durum material. Crop Pasture Sci 2014, 65:46-51.

8. Tomassini A, Sella L, Raiola A, D'Ovidio R, Favaron F: Characterization and expression of Fusarium graminearum endo-polygalacturonases in vitro and during wheat infection. Plant Pathol 2009, 58:556-564

9. Wanyoike MW, Kang Z, Heinrich B: Importance of Cell Wall Degrading Enzymes Produced by Fusarium graminearum during Infection of Wheat Heads. Eur J PI Pathol 2002, 108:803-810.

10. Yang F, Jensen JD, Svensson B, Jorgensen HJL, Collinge DB, Finnie C Secretomics identifies Fusarium graminearum proteins involved in the interaction with barley and wheat. Mol Plant Pathol 2012, 13:445-453. 
11. Bellincampi D, Cervone F, Lionetti V: Plant cell wall dynamics and wallrelated susceptibility in plant-pathogen interactions. Front Plant Sci 2014 5:228

12. Cantu D, Vicente AR, Labavitch JM, Bennett AB, Powell AL: Strangers in the matrix: plant cell walls and pathogen susceptibility. Trends Plant Sci 2008 13:610-617.

13. Pogorelko G, Lionetti V, Bellincampi D, Zabotina O: Cell wall integrity: Targeted post-synthetic modifications to reveal its role in plant growth and defense against pathogens. Plant Signal Behav 2013, 8:e25435.

14. Blümke A, Falter C, Herrfurth C, Sode B, Bode R, Schäfer W, Feussner I, Voigt CA: Secreted fungal effector lipase releases free fatty acids to inhibit innate immunity-related callose formation during wheat head infection. Plant Physiol 2014, 165:346-358.

15. King BC, Waxman KD, Nenni NV, Walker LP, Bergstrom GC, Gibson DM: Arsenal of plant cell wall degrading enzymes reflects host preference among plant pathogenic fungi. Biotechnol Biofuels 2011, 4:4.

16. Vogel J: Unique aspects of the grass cell wall. Curr Opin Plant Bio/ 2008 11:301-307

17. Rennie EA, Scheller HV: Xylan biosynthesis. Curr Opin Biotechnol 2014 26:100-107.

18. Berrin JG, Juge N: Factors affecting xylanase functionality in the degradation of arabinoxylans. Biotechnol Lett 2008, 30:1139-1150

19. Fincher GB: Revolutionary Times in Our Understanding of Cell Wall Biosynthesis and Remodeling in the Grasses. Plant Physiol 2009, 149:27-37.

20. Lionetti V, Cervone F, Bellincampi D: Methyl esterification of pectin plays a role during plant-pathogen interactions and affects plant resistance to diseases. J Plant Physiol 2012, 169:1623-1630.

21. Chanliaud E, Gidley MJ: In vitro synthesis and properties of pectin/ Acetobacter xylinus cellulose composites. Plant J 1999, 20:25-35.

22. Yoneda A, Ito T, Higaki T, Kutsuna N, Saito T, Ishimizu T, Osada H, Hasezawa S, Matsui M, Demura T: Cobtorin target analysis reveals that pectin functions in the deposition of cellulose microfibrils in parallel with cortical microtubules. Plant J 2010, 64:657-667.

23. Koshijima T, Watanabe T: Association between lignin and carbohydrates in wood and other plant tissues. Springer-Verlag; Springer, Berlin; 2003.

24. Caffall KH, Mohnen D: The structure, function, and biosynthesis of plant cell wall pectic polysaccharides. Carbohydr Res 2009, 344:1879-1900

25. Lionetti V, Francocci F, Ferrari S, Volpi C, Bellincampi D, Galletti $R$, D'Ovidio R, De Lorenzo G, Cervone F: Engineering the cell wall by reducing de-methyl-esterified homogalacturonan improves saccharification of plant tissues for bioconversion. Proc Natl Acad SCl US A 2010, 107:616-621

26. Willats WG, McCartney L, Mackie W, Knox JP: Pectin: cell biology and prospects for functional analysis. Plant Mol Biol 2001, 47:9-27.

27. Bonnin E, Le Goff A, Korner R, Vigouroux J, Roepstorff P, Thibault JF: Hydrolysis of pectins with different degrees and patterns of methylation by the endopolygalacturonase of Fusarium moniliforme. Biochim Biophys Acta 2002, 1596:83-94

28. Limberg G, Korner R, Buchholt HC, Christensen TM, Roepstorff $P$, Mikkelsen JD: Analysis of different de-esterification mechanisms for pectin by enzymatic fingerprinting using endopectin lyase and endopolygalacturonase II from A. niger. Carbohydr Res 2000, 327:293-307.

29. Wietholter N, Graessner B, Mierau M, Mort AJ, Moerschbacher BM: Differences in the methyl ester distribution of homogalacturonans from near-isogenic wheat lines resistant and susceptible to the wheat stem rust fungus. Mol Plant Microbe Interact 2003, 16:945-952

30. Volpi C, Raiola A, Janni M, Gordon A, O'Sullivan DM, Favaron F, D'Ovidio R: Claviceps purpurea expressing polygalacturonases escaping PGIP inhibition fully infects PvPGIP2 wheat transgenic plants but its infection is delayed in wheat transgenic plants with increased level of pectin methyl esterification. Plant Physiol Biochem 2013, 73:294-301.

31. Baucher M, Monties B, Van Montagu M, Boerjan W: Biosynthesis and genetic engineering of lignin. Crit Rev Plant Sci 1998, 17:125-197.

32. Vanholme R, Demedts B, Morreel K, Ralph J, Boerjan W: Lignin Biosynthesis and Structure. Plant Physiol 2010, 153:895-905.

33. Sattler SE, Funnell-Harris DL: Modifying lignin to improve bioenergy feedstocks: strengthening the barrier against pathogens? Front Plant Sci 2013, 4:70. doi:10.3389/fpls.2013.00070.
34. Haidukowski M, Visconti A, Perrone G, Vanadia S, Pancaldi D, Covarelli L, Balestrazzi R, Pascale M: Effect of prothioconazole-based fungicides on Fusarium head blight, grain yield and deoxynivalenol accumulation in wheat under field conditions. Phytopathol Mediterr 2012, 51:236-246.

35. Schroeder HW, Christensen JJ: Factors affecting resistance of wheat to scab caused by Gibberella zeae. Phytopathology 1963, 53:831-838.

36. Skyba O, Douglas CJ, Mansfield SD: Syringyl-Rich Lignin Renders Poplars More Resistant to Degradation by Wood Decay Fungi. Appl Environ Microbiol 2013, 79:2560-2571

37. Eynck C, Seguin-Swartz G, Clarke WE, Parkin IAP: Monolignol biosynthesis is associated with resistance to Sclerotinia sclerotiorum in Camelina sativa. Mol Plant Pathol 2012, 13:887-899.

38. Chen F, Reddy MSS, Temple S, Jackson L, Shadle G, Dixon RA: Multi-site genetic modulation of monolignol biosynthesis suggests new routes for formation of syringyl lignin and wall-bound ferulic acid in alfalfa (Medicago sativa L.). Plant J 2006, 48:113-124.

39. Bhuiyan NH, Selvaraj G, Wei YD, King J: Gene expression profiling and silencing reveal that monolignol biosynthesis plays a critical role in penetration defence in wheat against powdery mildew invasion. $J$ Exp Bot 2009, 60:509-521.

40. Gomez LD, Bristow JK, Statham ER, McQueen-Mason SJ: Analysis of saccharification in Brachypodium distachyon stems under mild conditions of hydrolysis. Biotechnol Biofuels 2008, 1:15.

41. Carpita NC, Defernez M, Findlay K, Wells B, Shoue DA, Catchpole G, Wilson RH, McCann MC: Cell wall architecture of the elongating maize coleoptile. Plant Physiol 2001, 127:551-565.

42. McCartney L, Marcus SE, Knox JP: Monoclonal antibodies to plant cell wall xylans and arabinoxylans. J Histochem Cytochem 2005, 53:543-546.

43. Beaugrand J, Croner D, Debeire P, Chabbert B: Arabinoxylan and hydroxycinnamate content of wheat bran in relation to endoxylanase susceptibility. J Cereal Sci 2004, 40:223-230.

44. Bily AC, Reid LM, Taylor JH, Johnston D, Malouin C, Burt AJ, Bakan B, Regnault-Roger C, Pauls KP, Arnason JT, Philogène BJ: Dehydrodimers of ferulic acid in maize grain pericarp and aleurone: Resistance factors to Fusarium graminearum. Phytopathol 2003, 93:712-719.

45. Santiago R, Malvar RA: Role of Dehydrodiferulates in Maize Resistance to Pests and Diseases. Int J Mol Sci 2010, 11:691-703.

46. Ralph J, Guillaumie S, Grabber JH, Lapierre C, Barriere Y: Genetic and molecular basis of grass cell-wall biosynthesis and degradability. III. Towards a forage grass ideotype. C R Biol 2004, 327:467-479.

47. Molinari HBC, Pellny TK, Freeman J, Shewry PR, Mitchell RAC: Grass cell wall feruloylation: distribution of bound ferulate and candidate gene expression in Brachypodium distachyon. Front Plant Sci 2013, 4:50. doi:10.3389/fpls.2013.00050

48. Ishii T: Isolation and characterization of a diferuloyl arabinoxylan hexasaccharide from bamboo shoot cell-walls. Carbohydr Res 1991, 219:15-22.

49. Anders N, Wilkinson MD, Lovegrove A, Freeman J, Tryfona T, Pellny TK, Weimar T, Mortimer JC, Stott K, Baker JM, Defoin-Platel M, Shewry PR, Dupree $P$, Mitchell RA: Glycosyl transferases in family 61 mediate arabinofuranosyl transfer onto xylan in grasses. Proc Natl Acad Sci U S A 2012, 109:989-993.

50. Chowdhury J, Henderson M, Schweizer P, Burton RA, Fincher GB, Little A: Differential accumulation of callose, arabinoxylan and cellulose in nonpenetrated versus penetrated papillae on leaves of barley infected with Blumeria graminis f. sp. hordei. New Phytol 2014, 204:650-660.

51. Burton RA, Wilson SM, Hrmova M, Harvey AJ, Shirley NJ, Stone BA, Newbigin EJ, Bacic A, Fincher GB: Cellulose synthase-like CsIF genes mediate the synthesis of cell wall $(1,3 ; 1,4)$-beta-D-glucans. Science 2006, 311:1940-1942.

52. Doblin MS, Pettolino FA, Wilson SM, Campbell $R$, Burton RA, Fincher GB, Newbigin E, Bacic A: A barley cellulose synthase-like CSLH gene mediates $(1,3 ; 1,4)$-beta-D-glucan synthesis in transgenic Arabidopsis. Proc Natl Acad Sci U S A 2009, 106:5996-6001.

53. Slikova S, Havrlentova M, Sudyova V, Mihalik D, Gregova E: Cell wall beta-Dglucan during disease progress (Fusarium head blight) in wheat spikes. Cereal Res Commun 2008, 36:167-169.

54. Clausen MH, Willats WGT, Knox JP: Synthetic methyl hexagalacturonate hapten inhibitors of antihomogalacturonan monoclonal antibodies LM7, JIM5 and JIM7. Carbohydr Res 2003, 338:1797-1800. 
55. Willats WG, Orfila C, Limberg G, Buchholt HC, van Alebeek GJ, Voragen AG, Marcus SE, Christensen TM, Mikkelsen JD, Murray BS, Knox JP: Modulation of the degree and pattern of methyl esterification of pectic homogalacturonan in plant cell walls: implications for pectin methyl esterase action, matrix properties and cell adhesion. J Biol Chem 2001, 276:19404-19413.

56. Raiola A, Lionetti V, Elmaghraby I, Immerzeel P, Mellerowicz EJ, Salvi G, Cervone F, Bellincampi D: Pectin methylesterase is induced in Arabidopsis upon infection and is necessary for a successful colonization by necrotrophic pathogens. Mol Plant-Microbe Interact 2011, 24:432-440.

57. Bethke G, Grundman RE, Sreekanta S, Truman W, Katagiri F, Glazebrook J: Arabidopsis PECTIN METHYLESTERASES Contribute to Immunity Against Pseudomonas syringae. Plant Physiol 2014, 164:1093-1107.

58. Lionetti V, Raiola A, Cervone F, Bellincampi D: Transgenic expression of pectin methylesterase inhibitors limits tobamovirus spread in tobacco and Arabidopsis. Mol Plant Pathol 2014, 15:265-274.

59. Phalip V, Goubet F, Carapito R, Jeltsch JM: Plant Cell Wall Degradation with a Powerful Fusarium graminearum Enzymatic Arsenal. J Microbiol Biotechnol 2009, 19:573-581.

60. De Lorenzo G, Castoria R, Bellincampi D, Cervone F: Fungal invasion enzymes and their inhibition. In The Mycota. V. Plant Relationships, Part B. Edited by Carroll GC, Tudzynski P. Berlin: Springer-Verlag; 1997:61-83.

61. Aleandri MP, Magro P, Chilosi G: Modulation of host pH during the wheatFusarium culmorum interaction and its influence on the production and activity of pectolytic enzymes. Plant Pathol 2007, 56:517-525.

62. Kikot GE, Hours RA, Alconada TM: Contribution of cell wall degrading enzymes to pathogenesis of Fusarium graminearum: a review. J Basic Microbiol 2009, 49:231-241.

63. Ferrari S, Sella L, Janni M, De Lorenzo G, Favaron F, D'Ovidio R: Transgenic expression of polygalacturonase-inhibiting proteins in Arabidopsis and wheat increases resistance to the flower pathogen Fusarium graminearum. Plant Biol 2011, 31:8. doi: 10.1111/j.1438-8677.2011.00449.x.

64. Jolie RP, Duvetter T, Van Loey AM, Hendrickx ME: Pectin methylesterase and its proteinaceous inhibitor: a review. Carbohydr Res 2010, 345:2583-2595.

65. Reca IB, Lionetti V, Camardella L, D'Avino R, Giardina T, Cervone F, Bellincampi D: A functional pectin methylesterase inhibitor protein (SolyPMEI) is expressed during tomato fruit ripening and interacts with PME-1. Plant Mol Biol 2012, 79:429-442.

66. Ma L, Jiang S, Lin GM, Cai JH, Ye XX, Chen HB, Li MH, Li HP, Takac T, Samaj J, Xu C: Wound-induced pectin methylesterases enhance banana (Musa spp. AAA) susceptibility to Fusarium oxysporum f. sp cubense. J Exp Bot 2013, 64:2219-2229.

67. Brkljacic J, Grotewold E, Scholl R, Mockler T, Garvin DF, Vain P, Brutnell T, Sibout R, Bevan M, Budak H, Caicedo AL, Gao C, Gu Y, Hazen SP, Holt BF 3rd, Hong SY, Jordan M, Manzaneda AJ, Mitchell-Olds T, Mochida K, Mur LA, Park CM, Sedbrook J, Watt M, Zheng SJ, Vogel JP: Brachypodium as a Model for the Grasses: Today and the Future. Plant Physio/ 2011 157:3-13

68. Wang MJ, Yuan DJ, Gao WH, Li Y, Tan JF, Zhang XL: A Comparative Genome Analysis of PME and PMEl Families Reveals the Evolution of Pectin Metabolism in Plant Cell Walls. PLoS One 2013, 8:e72082.

69. Chen SQ, Huang ZF, Dai Y, Qin SW, Gao YY, Zhang LL, Gao Y, Chen JM: The Development of 7E Chromosome-Specific Molecular Markers for Thinopyrum elongatum Based on SLAF-seq Technology. PLoS One 2013, 8:e65122.

70. Walter S, Nicholson P, Doohan FM: Action and reaction of host and pathogen during Fusarium head blight disease. New Phytol 2010, 185:54-66.

71. Jansen C, von Wettstein D, Schafer W, Kogel KH, Felk A, Maier FJ: Infection patterns in barley and wheat spikes inoculated with wild-type and trichodiene synthase gene disrupted Fusarium graminearum. Proc Natl Acad Sci U S A 2005, 102:16892-16897.

72. Buerstmayr M, Huber K, Heckmann J, Steiner B, Nelson JC, Buerstmayr H: Mapping of QTL for Fusarium head blight resistance and morphological and developmental traits in three backcross populations derived from Triticum dicoccum x Triticum durum. Theor Appl Genet 2012 125:1751-1765

73. Ban T, Watanabe N: The effects of chromosomes $3 \mathrm{~A}$ and $3 \mathrm{~B}$ on resistance to Fusarium head blight in tetraploid wheat. Hereditas 2001, 135:95-99.
74. Pelegrini PB, Franco OL: Plant gamma-thionins: Novel insights on the mechanism of action of a multi-functional class of defense proteins. Int J Biochem Cell Biol 2005, 37:2239-2253.

75. Deepak S, Shailasree S, Kini RK, Muck A, Mithofer A, Shetty SH: Hydroxyproline-rich Glycoproteins and Plant Defence. J Phytopathol 2010, 158:585-593.

76. Janni M, Sella L, Favaron F, Blechl AE, De Lorenzo G, D'Ovidio R: The expression of a bean polygalacturonase-inhibiting proteins in transgenic wheat confers increased resistance to the fungal pathogen Bipolaris sorokiniana. Mol Plant-Microbe Interact 2008, 21:171-177.

77. Fukushima RS, Hatfield RD: Comparison of the acetyl bromide spectrophotometric method with other analytical lignin methods for determining lignin concentration in forage samples. J Agric Food Chem 2004, 52:3713-3720.

78. Sasaki M, Yamamoto Y, Matsumoto H: Lignin deposition induced by aluminum in wheat (Triticum aestivum) roots. Physiol Plant 1996 96:193-198.

79. Ralph J, Hatfield RD: Pyrolysis-Gc-Ms Characterization of Forage Materials. J Agric Food Chem 1991, 39:1426-1437.

80. Klavons JA, Bennett RD: Determination of methanol using alcohol oxidase and its application to methyl ester content of pectins. $J$ Agric Food Chem 1986, 34:597-599.

81. Filisetti-Cozzi TMCC, Carpita NC: Measurement of uronic acids without interference from neutral sugars. Anal Biochem 1991, 197:157-162.

82. Updegraff DM: Semimicro determination of cellulose in biological material. Anal Biochem 1969, 32:420-424.

83. Scott TA Jr, Melvin EH: Determination of dextran with anthrone. Anal Chem 1953, 25:1656-1661.

84. Willats WG, Limberg G, Buchholt HC, van Alebeek GJ, Benen J, Christensen TM, Visser J, Voragen A, Mikkelsen JD, Knox JP: Analysis of pectic epitopes recognised by hybridoma and phage display monoclonal antibodies using defined oligosaccharides, polysaccharides, and enzymatic degradation. Carbohydr Res 2000, 327:309-320.

85. Dellaporta SL, Wood J, Hicks JB: A plant DNA minipreparation: version II. Plant Mol Biol Rep 1983, 1:19-21.

86. Sears ER: The aneuploids of common wheat. Mo Agric Exp Stn Res Bull 1954, 572:1-58.

87. Sears ER: Nullisomic-tetrasomic combinations in hexaploid wheat. In: Chromosome manipulations and plant genetics. Riley R. and Lewis K.R. edition. Oliver \& Boyd, Edinburgh; 1966:29-45.

88. Sears ER, Sears LMS: The telocentric chromosomes of common wheat Edited by Ramanujam S. Proc. 5th Int Wheat Genetics Symp New Dehli, Indian Agricultural Research Institute 1978:389-407.

89. Endo TR, Gill BS: The deletion stocks of common wheat. J Hered 1996 87:295-307

\section{Submit your next manuscript to BioMed Central and take full advantage of:}

- Convenient online submission

- Thorough peer review

- No space constraints or color figure charges

- Immediate publication on acceptance

- Inclusion in PubMed, CAS, Scopus and Google Scholar

- Research which is freely available for redistribution 